\title{
Calendula officinalis stimulate proliferation of mouse embryonic fibroblasts via expression of growth factors TGF $\beta 1$ and bFGF
}

\author{
Maryam Hormozi ${ }^{1,2}$, Mohammadreza Gholami ${ }^{3}$, Ayda Babaniazi ${ }^{4}$ and Anneh Mohammad Gharravi ${ }^{5^{*}}$
}

\begin{abstract}
Background: TGF- $\beta$ has an important role in the process of wound healing and scar formation. The aim of this study is to determine the effects of ethanolic and methanolic extracts of Calendula officinalis on the expression of TGF $\beta 1$ and bFGF in the mouse embryonic fibroblast cells (MEFs).

Methods: Calendula officinalis extract was purchased and different substances defined with gas chromatography and mass spectrometry. MEFs were prepared and after incubating for $15 \mathrm{~min}$, cell viability analyzed. TGF $\beta 1$ and bFGF gene expression was evaluated by real-time PCR. TGF 31 and bFGF protein expression analyzed by ELISA. The statistical analysis of data was done by using SPSS software. Differences were considered significant at $(P<0.05)$.

Results: The results of the MTT test showed that the concentrations of $5 \mu \mathrm{g} / \mathrm{ml}$ and $10 \mu \mathrm{g} / \mathrm{ml}$ were more suitable for cell proliferation. There was an increase in TGF $\beta 1$ gene expression in the MEFs. Expression of TGF $\beta 1$ gene remains the same after $24 \mathrm{~h}$. Gene expression of bFGF showed a similar pattern with TGF $\beta 1$ expression for both solvents. Analysis of TGF $\beta 1$ protein expression showed an increase in TGF $\beta 1$ gene expression in the MEFs. Protein expression of bFGF in the MEFs increased at different concentrations at 12 and $24 \mathrm{~h}$ after treatment $(P<0.05$ and $P<0.01$ respectively).
\end{abstract}

Conclusion: Calendula officinalis stimulates proliferation of MEFs. Calendula via increased expression of growth factors (TGF $\beta 1$ and bFGF) at the first $12 \mathrm{~h}$ and a decrease of these factors at $24 \mathrm{~h}$ after treatment may ameliorate function of the MEFs in the during wound healing.

Keywords: Calendula officinalis, bFGF, TGFß1, Mouse embryonic fibroblasts

\section{Background}

Growth of new tissue and scar formation are two important issues in tissue injury. Fibroblasts are the main cells in the wound healing process because they migrate and proliferate to the injury site after 2 or 3 days. Then, the cells produce extracellular matrix especially collagen. Growth factors play important roles in the proliferation, migration, and production of ECM substances by fibroblasts. Recently, researches showed that the

\footnotetext{
* Correspondence: annehgh@yahoo.com; gharravi@shmu.ac.ir

${ }^{5}$ Tissue Engineering and Stem Cells Research Center, Shahroud University of Medical Sciences, Shahroud, Iran

Full list of author information is available at the end of the article
}

growth factor TGF- $\beta$ has an important role in the process not only in wound healing but also in scar formation. TGF- $\beta$ applies their effects via the intracellular SMAD pathway. $[1,2]$. It has been shown that TGF $\beta 1$ activates angiogenesis by stimulating vascular smooth muscle cell migration [3-5]. The importance of this factor in creating and maintaining the vascular system has been proved by numerous studies. TGF $\beta 1$ and its receptors lead to fetal death due to impaired vessel formation [6, 7]. TGF $\beta 1$ induces the maturation of retinoic acid-inducible gene I (RIGI), therefore, stimulates the formation and intensification of interaction between epithelial cells and the basement membrane of the mural cells [8-10]. Also bFGF, (FGF 2 or FGF- $\beta$ ) contribute to 
control of endothelial cells and fibroblasts migration, which are responsible for angiogenesis and collagen formation of the epithelial layer $[1,9,11]$.

Calendula officinalis L. (Asteraceae) has been traditionally used in the treatment of various diseases such as skin tumors, dermatological lesions, and swellings. Despite a long tradition of use of Calendula officinalis L., the biological aspect of its activity has not been explored properly. Recent research supports the medicinal potential of Calendula officinalis L. Calendula officinalis L. properties need to be investigated to determine their varied biological activities and mechanism of actions. To determine the effectiveness of the Calendula officinalis L. in the treatment of dermatologic disorders, more research is necessary to understand the action mechanism of this plant. Therefore, the aim of this study is to determine the effect of the Calendula officinalis L. extract on proliferation and expression of two important growth factors, TGF $\beta 1$ and bFGF, at the MEFs.

\section{Materials and methods}

\section{Preparation of Calendula officinalis extract}

Twenty grams of dried flowers of Calendula officinalis were collected from Lorestan Agricultural and Natural Resources Research and Education Center and soaked in $120 \mathrm{ml}$ of $50 \%$ ethanol or methanol for $72 \mathrm{~h}$ in a dark. In the next step, it was centrifuged and passed through the filter and dried at room temperature to yield $8.7 \% \mathrm{w} / \mathrm{w}$ extract. Then the extract was stored at $-20^{\circ} \mathrm{C}$ until further use.

\section{GC-MS analysis of Calendula officinalis extract}

Different substances within Calendula officinalis extract defined with gas chromatography and mass spectrometry (GC-MS) at the Lorestan University.

\section{Isolation and culture of MEFs}

Isolation and culture of mouse embryonic fibroblasts (MEFs) were performed according to the protocol described elsewhere [12]. In the brief, a pregnant mouse at 13 or 14 days post-coitum (d.p.c) was sacrificed by dislocating of cervical vertebrae and uterine horns were dissected and rinsed in 70\% $(v / v)$ ethanol and placed into a Falcon tube with PBS buffer, without calcium and magnesium ions. The embryos were separated from its embryonic sac and placenta. Then, $1 \mathrm{ml}$ of $0.05 \%$ trypsin/ EDTA (Gibco, Invitrogen) containing $100 \mathrm{~K}$ units of DNase I per each embryo was added and incubated at the room temperature for $15 \mathrm{~min}$. Cells were dissociated by pipetting each $5 \mathrm{~min}$. Trypsin inactivated by the addition of 1 volume of freshly prepared MEF medium. Then, cells were centrifuged and the cell pellet was washed in warm MEF medium.

\section{MTT assay}

To evaluate cell viability, fibroblast cells incubated with different concentrations of Calendula officinalis $(5 \mu \mathrm{g} / \mathrm{ml}$, $10 \mu \mathrm{g} / \mathrm{ml}, 20 \mu \mathrm{g} / \mathrm{ml}, 40 \mu \mathrm{g} / \mathrm{ml}$, and $50 \mu \mathrm{g} / \mathrm{ml}$ ) for $12,24,48$, and $72 \mathrm{~h}$. Then, $20 \mu \mathrm{l}$ of MTT $(5 \mathrm{mg} / \mathrm{ml}$, Sigma) in PBS solution added into each of the wells, and the plate was further incubated for $4 \mathrm{~h}$. In the next step, $200 \mu \mathrm{l}$ of DMSO added into each well, incubated for $15 \mathrm{~min}$ to dissolve the formed crystal formation and the light absorption measured using an enzyme-linked immunosorbent assay (ELISA) reader. Cell viability expressed as a percentage of absorbance values in treating cells.

\section{Analysis of TGF $\beta 1$ and bFGF gene expression by real- time PCR}

MEFs were exposed to different concentrations of ethanolic and methanolic Calendula officinalis extracts $(5 \mu \mathrm{g} / \mathrm{ml}$ and $10 \mu \mathrm{g} / \mathrm{ml}$ ) and then, cells were collected at 12 and $24 \mathrm{~h}$ using trypsin/EDTA. Total RNA isolated and the concentration and purity of RNA determined using biophotometer (Eppendorf, Hamburg, Germany). The concentration and quality of the RNA samples confirmed by electrophoresis on 1\% denatured agarose gel.

Following procedures were performed:

1) Generation of first strand cDNA with $1 \mu \mathrm{g}$ total RNA using the cDNA Synthesis Kit (Roche Diagnostics GmbH, Mannheim, Germany).

2) Selection of HPRT as the housekeeping gene.

3) Real-time quantitative PCR by using Rotor-Gene 6000 and SYBR-Green quantitative PCR (qPCR) kit (Jena Bioscience, Cat No. 311S)

Oligonucleotide sequences of the primers and their characteristics are presented in Table 1.

Analysis of TGF $\beta 1$ and bFGF protein expression by ELISA MEFs were cultured in 6-well plates $\left(10^{5}\right.$ cell per well) and were exposed to ethanolic and methanolic extract of Calendula officinalis $(5 \mu \mathrm{g} / \mathrm{ml}, 10 \mu \mathrm{g} / \mathrm{ml})$ and supernatant were collected at 12 and $24 \mathrm{~h}$. Samples were frozen at $-20^{\circ} \mathrm{C}$. TGF- $\beta 1$ protein concentration in cell culture supernatants was measured by Ready-Set-GO TGF- $\beta 1$ cytokine ELISA kit from eBioscience (San Diego, CA,

Table 1 Sequences of primers for real-time quantitative PCR

\begin{tabular}{llcc}
\hline Gene & Primer & Product size & Tm \\
\hline HPRT & Sense:CCTCCTCAGACCGCTTTTT & 91 & 79.5 \\
& Antisense:AACCTGGTTCATCATCGCTAA & & \\
FGF2 & Sense: AACGGCGGCTTCTTCCTG & 133 & 78.9 \\
& Antisense:TGGCACACACTCCCTTGATAG & & \\
TGFß1 & Sense: ATTCCTGGCGTTACCTTGG & 117 & 76.9 \\
& Antisense:CCTGTATTCCGTCTCCTTG & & \\
\hline
\end{tabular}


USA, Catalog Number: 88-8350) and FGF ELISA kit (Cat no. ELH-bFGF-001; RayBiotech, Inc., St. Louis, MO).

\section{Statistical analysis}

The statistical analysis of data was done by using SPSS software. Differences between the groups were analyzed by using Wilcoxon test. Differences were considered significant at $(P<0.05)$.

\section{Results}

\section{GC-MS analysis}

GC-MS analysis showed that the main components present in the Calendula officinalis extract are carvacrol, thymol, ethyl hexadecanoate, and viridiflorene (Table 2).

\section{Effect of Calendula officinalis extract on MEFs viability}

The results of MTT assay to determine if Calendula officinalis ethanolic/methanolic extract affects cell viability of MEFs at different concentration $(5 \mu \mathrm{g} / \mathrm{ml}, 10 \mu \mathrm{g} / \mathrm{ml}$, $20 \mu \mathrm{g} / \mathrm{ml}, 40 \mu \mathrm{g} / \mathrm{ml}$ ) showed that the Calendula officinalis extract using both solvents was non-toxic to the cells. The concentrations of $5 \mu \mathrm{g} / \mathrm{ml}$ and $10 \mu \mathrm{g} / \mathrm{ml}$ were more suitable for cell proliferation. Therefore, this study was evaluated in these concentrations (Fig. 1).

\section{TGF $\beta 1$ and $b F G F$ gene expression}

Analysis of TGF $\beta 1$ gene expression for the ethanolic extract (Fig. 2a) and the methanolic extract (Fig. 2b), revealed an increase TGF $\beta 1$ gene expression in the MEFs at different concentrations $(5 \mu \mathrm{g} / \mathrm{ml}, 10 \mu \mathrm{g} / \mathrm{ml})$ at $12 \mathrm{~h}$ after treatment $(P<0.05$ and $P<0.01$ respectively). But the expression of TGF $\beta 1$ gene remained the same $24 \mathrm{~h}$ at the two concentrations after treatment with ethanolic extract (Fig. 2a and Table 3). The methanolic extract results revealed an increase in the expression for the two extracts at $12 \mathrm{~h}$ and a decline in the expression of the gene

Table 2 GC-MS analysis showed that the main components present in the Calendula officinalis extract are carvacrol, thymol, ethyl hexadecanoate, and viridiflorene

\begin{tabular}{|c|c|c|c|c|c|}
\hline$t^{\prime} R(A)$ & $\mathrm{RI}($ Calc) & $\mathrm{RI}(\mathrm{STD})$ & Similarity & Compound name & Area (\%) \\
\hline 4.092 & 832.5714286 & 800 & $83 \%$ & Hexanal & 1.005961 \\
\hline 4.233 & 846 & 830 & $95 \%$ & Furfural & 1.415797 \\
\hline 4.375 & 859.5238095 & 851 & $92 \%$ & Furfuryl alcohol & 1.453055 \\
\hline 4.958 & 910.5333333 & 899 & $80 \%$ & Heptanal & 1.19225 \\
\hline 5.267 & 931.1333333 & 998 & $81 \%$ & Octanal & 1.254347 \\
\hline 5.933 & 975.5333333 & 957 & $94 \%$ & Furfural 5-methyl & 1.20467 \\
\hline 6.175 & 991.6666667 & 911 & $80 \%$ & Amyl acetate & 3.551913 \\
\hline 6.517 & 1010.432692 & 950 & $93 \%$ & Glycerin & 19.54794 \\
\hline 7.592 & 1062.115385 & 1112 & $80 \%$ & Heptyl acetate & 2.707402 \\
\hline 8.092 & 1086.153846 & 1106 & $77 \%$ & Maltol & 1.800795 \\
\hline 10.767 & 1185.402504 & 1171 & $70 \%$ & Umbellulone & 0.384998 \\
\hline 12.2 & 1230.191458 & 1228 & $85 \%$ & Citronellol & 1.477894 \\
\hline 14.433 & 1295.964654 & 1285 & $80 \%$ & Bornyl acetate & 0.471932 \\
\hline 14.642 & 1301.899736 & 1290 & $93 \%$ & Thymol & 1.328862 \\
\hline 14.967 & 1310.474934 & 1298 & $95 \%$ & Carvacrol & 7.19076 \\
\hline 19.658 & 1432.944162 & 1439 & $82 \%$ & Aromadendrene & 0.422255 \\
\hline 20.517 & 1454.746193 & 1458 & $87 \%$ & Beta Farnesene & 0.981123 \\
\hline 22.192 & 1497.258883 & 1467 & $83 \%$ & Caryophyllene & 0.695479 \\
\hline 22.467 & 1504.249364 & 1493 & $93 \%$ & Viridiflorene & 3.154496 \\
\hline 23.433 & 1528.829517 & 1524 & $91 \%$ & Delta Cadinene & 1.043219 \\
\hline 24.708 & 1561.272265 & 1549 & $90 \%$ & Elemol & 0.34774 \\
\hline 26.142 & 1597.760814 & 1600 & $90 \%$ & Hexadecane & 0.471932 \\
\hline 29.125 & 1674.806202 & 1658 & $80 \%$ & Eudesmol & 2.309985 \\
\hline 29.275 & 1678.682171 & 1691 & $80 \%$ & Juniper Camphor & 0.471932 \\
\hline 29.992 & 1697.209302 & 1700 & $87 \%$ & Heptadecane & 0.397417 \\
\hline 39.675 & 1967.424242 & 1959 & $90 \%$ & Hexadecanoic acid & 0.894188 \\
\hline 40.633 & 1996.454545 & 1993 & $93 \%$ & Ethyl hexadecanoate & 0.558867 \\
\hline
\end{tabular}



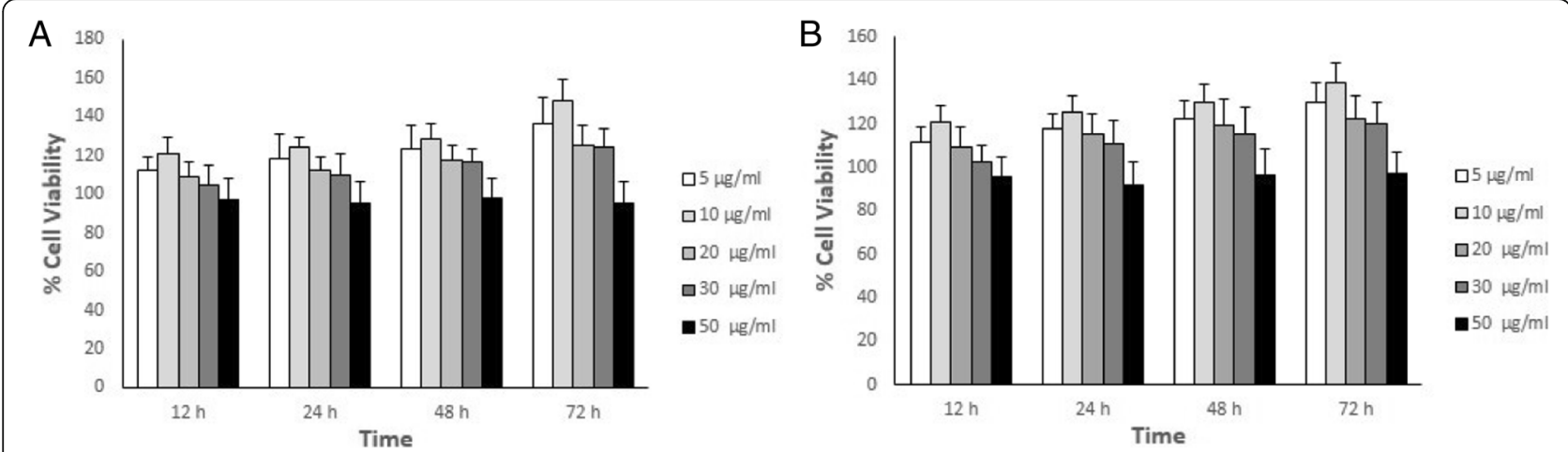

Fig. 1 Effect of ethanolic (a) and methanolic (b) extract of Calendula on MEFs viability. Cells were treated with different concentration of Calendula for $12,24,48$, and $72 \mathrm{~h}$ and cell viability was measured by MTT assay

at $24 \mathrm{~h}$ (Fig. $2 \mathrm{~b}$ and Table 4$)(P<0.05$ and $P<0.01$ respectively). Gene expression of $b F G F$ in the MEFs indicated a similar pattern with TGF $\beta 1$ expression for both solvent, an increase $b F G F$ gene expression in the MEFs at different concentrations $(5 \mu \mathrm{g} / \mathrm{ml}, 10 \mu \mathrm{g} / \mathrm{ml})$ at $12 \mathrm{~h}$ after treatment $(P<0.05$ and $P<0.01$ respectively). But the expression of $b F G F$ gene remained the same $24 \mathrm{~h}$ at the two concentrations after treatment with ethanolic extract (Fig. 3a and Table 5). The methanolic extract results indicated an increase in the expression for the two extracts at $12 \mathrm{~h}$ and a decline in the expression of the gene at $24 \mathrm{~h}$ (Fig. $3 \mathrm{~b}$ and Table 6) $(P<0.05$ and $P<0.01$ respectively) (Table 2$)$.

\section{TGF $\beta 1$ and bFGF protein expression}

Analysis of TGF $\beta 1$ protein expression of the ethanolic extract (Fig. 4a) and the methanolic extract (Fig. 4b) revealed an increase TGF $\beta 1$ gene expression in the MEFs at different concentrations $(5 \mu \mathrm{g} / \mathrm{ml}, 10 \mu \mathrm{g} / \mathrm{ml})$ at $12 \mathrm{~h}$ $(P<0.05$ and $P<0.01$ respectively). But the expression of TGF $\beta 1$ protein was slightly reduced, $24 \mathrm{~h}$ at the two concentrations after treatment with ethanolic extract (Fig. 4a). The methanolic extract results indicated a similar pattern (Fig. 4b) $(P<0.05$ and $P<0.01$ respectively).

Protein expression of bFGF in MEFs revealed an increase in bFGF protein expression at different concentrations $(5 \mu \mathrm{g} / \mathrm{ml}, 10 \mu \mathrm{g} / \mathrm{ml})$ of $12 \mathrm{~h}$ after treatment $(P<0.05$ and $P<0.01$ respectively). The same increasing pattern of bFGF protein expression was observed $24 \mathrm{~h}$ at the two concentrations after treatment with ethanolic extract. The methanolic extract results indicated a similar pattern with that of the ethanolic extract, as compared with the control $(P<0.05$ and $P<0.01$ respectively).

When the ethanolic and methanolic extracts of Calendula officinalis were compared, ethanolic extract indicated more effective to stimulate MEFs (Figs. 2, 3, and 4 and Tables 3, 4, 5, and 6).

\section{Discussion}

The results of the present study indicated that both methanol and ethanol extracts of Calendula officinalis
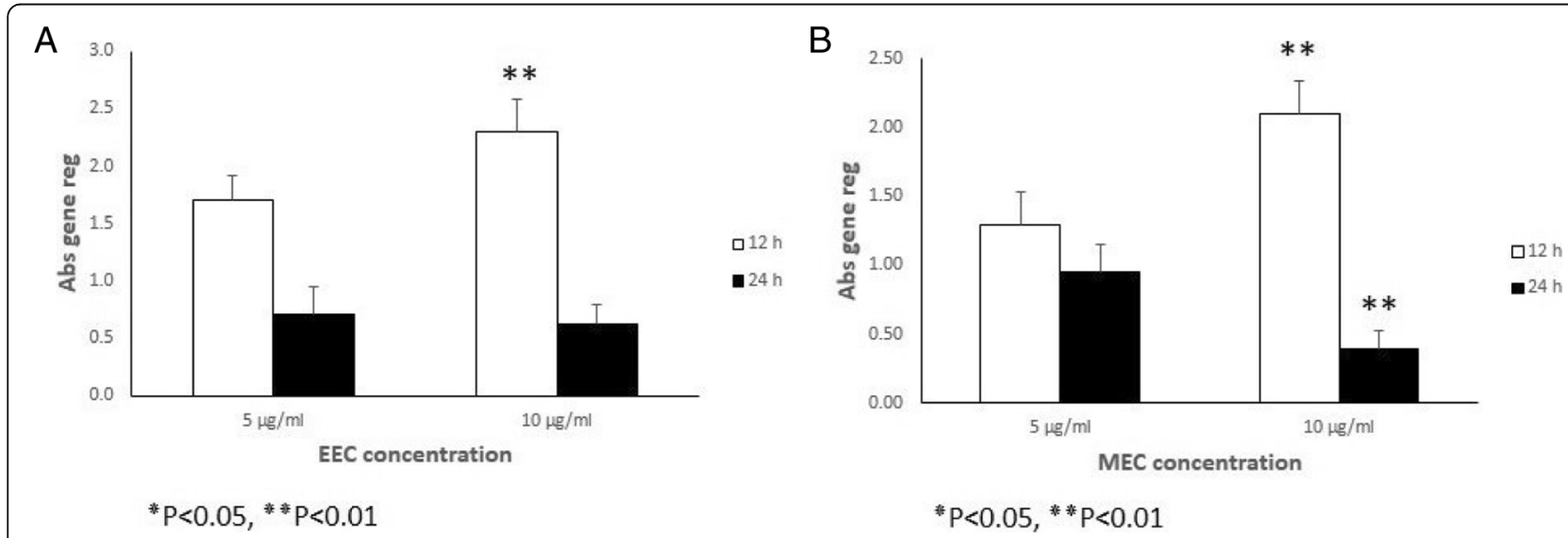

Fig. 2 Relative expression of TGF $\beta 1$ gene in the MEFs that were treated with various concentrations of ethanol (a) and methanol (b) extracts of Calendula at different time intervals treatment (12 and $24 \mathrm{~h}$ ). All comparisons were made compared to the control group. ${ }^{*} P<0.05,{ }^{* *} P<0.01$. Abs gene reg: Absolute gene regulation 
Table 3 The total expression ratio of the gene of TGFB1 in the MEFs treated with various concentrations of ethanol extract of Calendula ( 5 and $10 \mu \mathrm{g} / \mathrm{ml}$ ) relative to control group is presented in each time (12 and $24 \mathrm{~h}$ after treatment). The statistic test for significance is randomization re-allocation test, implemented in the relative expression software tool. Significant down or upregulations of the genes highlighted

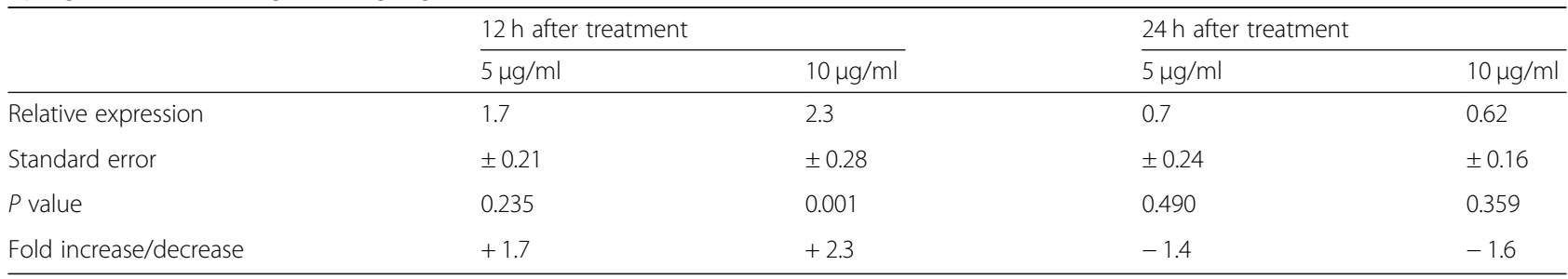

Table 4 The total expression ratio of the gene of TGFB1 in the MEFs treated with various concentrations of methanol extract of Calendula ( 5 and $10 \mu \mathrm{g} / \mathrm{ml}$ ) relative to control group is presented in each time (12 and $24 \mathrm{~h}$ after treatment). The statistic test for significance is randomization re-allocation test, implemented in the relative expression software tool. Significant down or upregulations of the genes highlighted

\begin{tabular}{lllll}
\hline & \multicolumn{1}{l}{$\frac{12 \mathrm{~h} \text { after treatment }}{5 \mu \mathrm{g} / \mathrm{ml}}$} & $10 \mu \mathrm{g} / \mathrm{ml}$ & \multicolumn{2}{c}{$24 \mathrm{~h}$ after treatment } \\
\cline { 2 - 5 } & $1.3 \mu \mathrm{g} / \mathrm{ml}$ & 0.7 & $10 \mu \mathrm{g} / \mathrm{ml}$ \\
\hline Relative expression & \pm 0.23 & 2.1 & \pm 0.2 & \pm .62 \\
Standard error & 0.265 & \pm 0.24 & 0.661 & 0.001 \\
$P$ value & +1.3 & 0.001 & -1.06 & -2.5 \\
Fold increase/decrease & & +2.1 & & \\
\hline
\end{tabular}
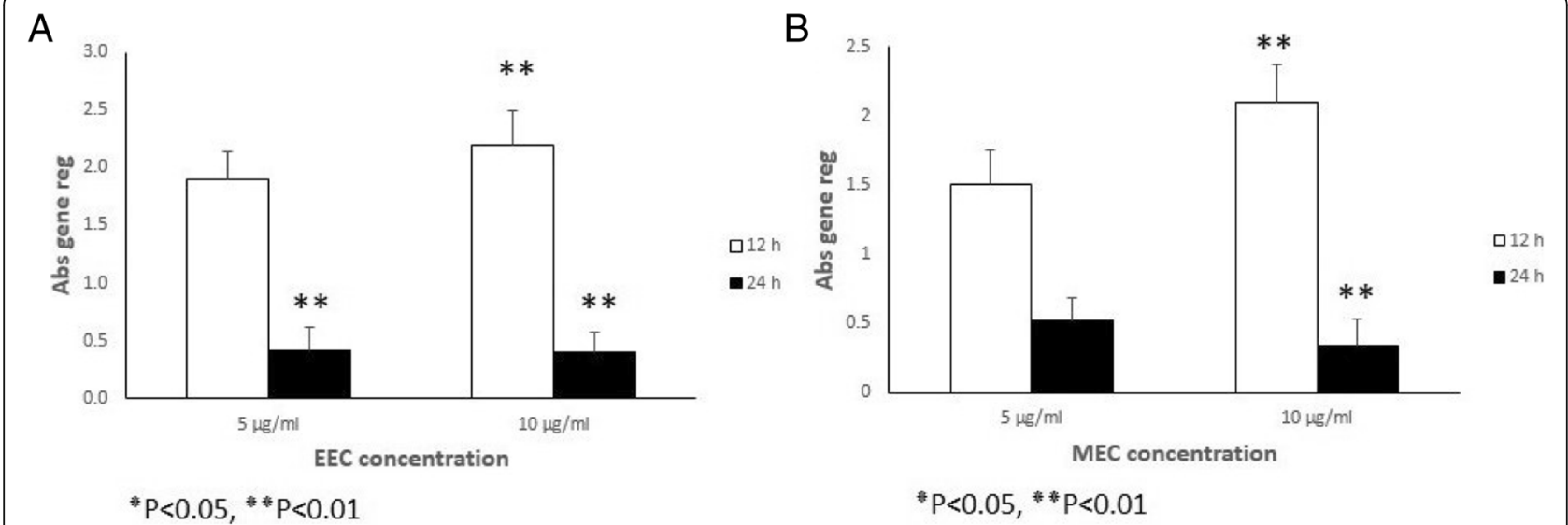

Fig. 3 Relative expression of $b F G F$ gene in the MEFs that were treated with various concentrations of ethanol (a) and methanol (b) extracts of Calendula at different time intervals treatment (12 and $24 \mathrm{~h}$ ). All comparisons were made compared to the control group. $\quad P<0.05, \quad P<0.01$. Abs gene reg: Absolute gene regulation

Table 5 The total expression ratio of the gene of bFGF in the MEFs treated with various concentration of ethanol extract of Calendula ( 5 and $10 \mu \mathrm{g} / \mathrm{ml}$ ) relative to control group is presented in each time (12 and $24 \mathrm{~h}$ after treatment). The statistic test for significance is randomization re-allocation test, implemented in the relative expression software tool. Significant down or upregulations of the genes highlighted

\begin{tabular}{lllll}
\hline & \multicolumn{1}{l}{$12 \mathrm{~h}$ after treatment } & & \multicolumn{2}{c}{$24 \mathrm{~h}$ after treatment } \\
\cline { 2 - 4 } & $5 \mu \mathrm{g} / \mathrm{ml}$ & 2.2 & 0.42 & $10 \mathrm{gg} / \mathrm{ml} / \mathrm{ml}$ \\
\hline Relative expression & 1.9 & \pm 0.29 & \pm 0.19 & \pm .39 \\
Standard error & \pm 0.24 & 0.001 & 0.001 & 0.001 \\
P- value & 0.256 & +2.2 & -2.4 & -2.5 \\
Fold increase/decrease & +1.9 & & \\
\hline
\end{tabular}


Table 6 The total expression ratio of the gene of bFGF in the MEFs treated with various concentration of methanol extract of Calendula (5 and $10 \mu \mathrm{g} / \mathrm{ml}$ ) relative to control group is presented in each time (12 and $24 \mathrm{~h}$ after treatment). The statistic test for significance is randomization re-allocation test, implemented in the relative expression software tool. Significant down or upregulations of the genes highlighted

\begin{tabular}{lllll}
\hline & \multicolumn{1}{l}{$12 \mathrm{~h}$ after treatment } & & $24 \mathrm{~h}$ after treatment \\
\cline { 2 - 4 } & $5 \mu \mathrm{g} / \mathrm{ml}$ & $10 \mu \mathrm{g} / \mathrm{ml}$ & $5 \mu \mathrm{g} / \mathrm{ml}$ & 0.52 \\
\hline Relative expression & 1.5 & 2.1 & \pm 0.17 & 0.34 \\
Standard error & \pm 0.25 & \pm 0.27 & 0.275 & 0.001 \\
$P$ value & 0.231 & 0.001 & -1.9 & -2.96 \\
Fold increase/decrease & +1.5 & +2.1 & 0.19 \\
\hline
\end{tabular}

had non-toxic effects of different concentration. The extracts similar to previous studies increased proliferation of the MEFs [13, 14]. Among different concentrations of Calendula extraction 5 and $10 \mu \mathrm{g} / \mathrm{ml}$ were more suitable for cell proliferation.

Previous investigation revealed that Calendula officinalis can inhibit collagen degradation and matrix metalloproteinase (MMP) activity, and induce neovascularization in the chorioallantoic membrane and skin wound.

Quercetin, one of the active components in Calendula, can decrease the expression of tumor necrosis factor- $\alpha$ (TNF- $\alpha$ ), interleukin-1 $\beta$, IL-6, and IL-8 [14-17].

During the wound healing process, fibroblasts play a crucial role. Then, the cells proliferate and migrate into the wound area, synthesis extracellular matrix (EXM), and the express of thick actin bundles as myofibroblasts [18, 19].

Important cytokines that produce by fibroblast are TGF $\beta 1$ and bFGF. TGF $\beta 1$ and bFGF impacts on cell division, cell migration, cell differentiation, protein expression, and enzyme production and have the potential ability to heal wounds through stimulation of angiogenesis factors and cellular proliferation which affects the ECM production and degradation through their chemotactic role on inflammatory cells and fibroblasts [20].

Several studies indicated that upregulation of TGF $\beta 1$ can stimulate the production of fibrotic disease [21, 22].

In the present study, Calendula officinalis increased TGF $\beta 1$ and bFGF at the first $12 \mathrm{~h}$ therefore stimulate wound healing. Then, the decrease of these factors at $24 \mathrm{~h}$ suppressed the expression of TGF $\beta 1$ and bFGF and may inhibit the fibrotic process. The Calendula at first may upregulate the expression of TGF $\beta 1$ and bFGF but after that may downregulate the expression of these genes.

\section{Conclusion}

Calendula officinalis not only shows no cytotoxicity effects on MEFs but also stimulates proliferation of these cells. Calendula via increased expression of growth factors (TGF $\beta 1$ and bFGF) at the first $12 \mathrm{~h}$, and a decrease of these factors at $24 \mathrm{~h}$ after treatment may ameliorate function of fibroblasts in the during wound healing.

\section{Abbreviations}

bFGF: Basic fibroblast growth factor; cDNA: Complementary deoxyribonucleic acid; DMEM: Dulbecco's modified Eagle's medium; ELISA: Enzyme-linked

immunosorbent assay; FBS: Fetal bovine serum; HPRT: Hypoxanthine

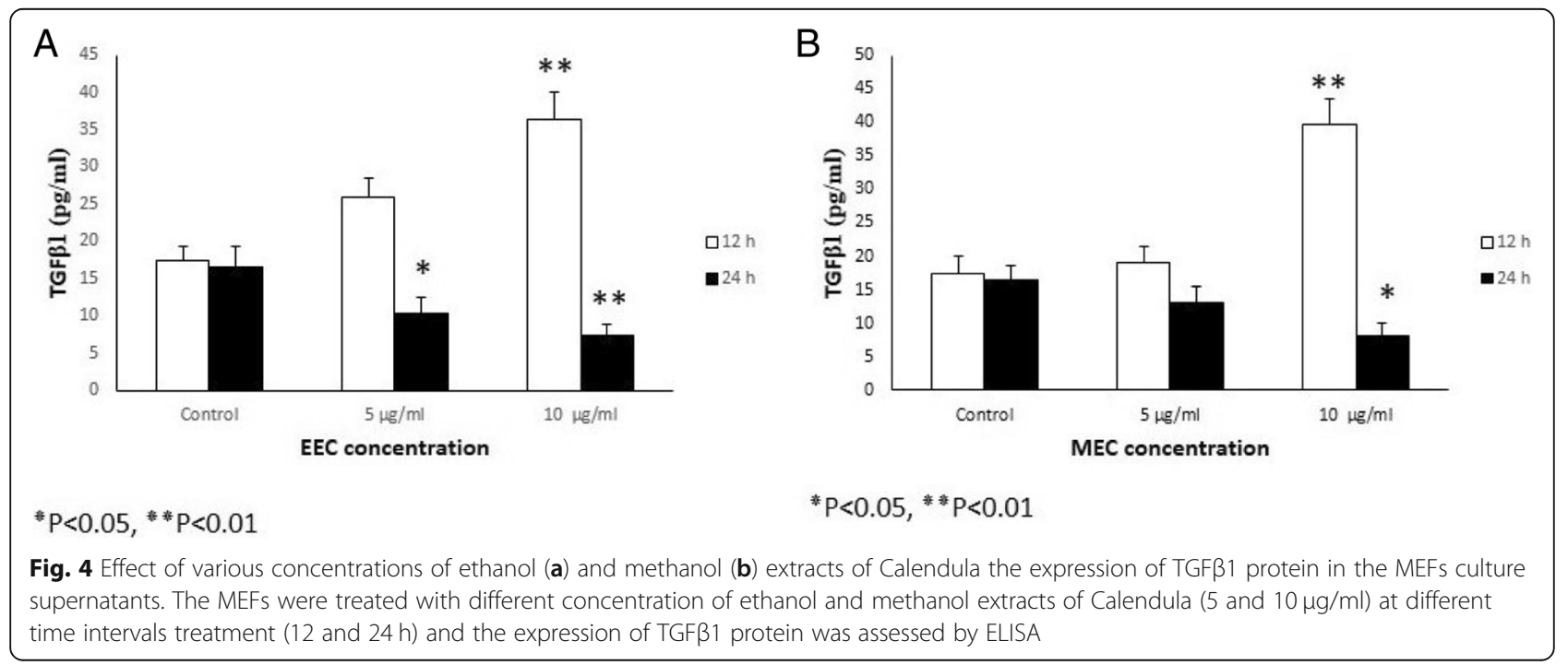


phosphoribosyltransferase; MEF: Mouse embryonic fibroblast; MTT: 3-(4, 5Dimethylthiazol-2-yl)-2, 5-diphenyltetrazolium bromide; nm: Nanometer; PBS: Phosphate-buffered saline; Pg/ml: Picograms per milliliter; Real-time PCR: Real-time polymerase chain reaction; TGF 31 : Transforming growth factor $\beta 1$; Tm: Melting temperature; TMB: 3, 3', 5, 5'-Tetramethylbenzidine

\section{Acknowledgements}

This work was supported by Lorestan University of Medical Science, Khorramabad, Iran

\section{Funding}

Not applicable.

\section{Availability of data and materials}

All data generated or analyzed during this study are included in this published article.

\section{Authors' contributions}

$M H, A B, M R G$, and $A M G$ devised the study concept and design. $M H$ and $A B$ collected the data. MG and AMG drafted the manuscript. All authors have seen and approved the manuscript.

\section{Ethics approval and consent to participate}

All of the experimental manuals on animals were conducted with agreement of protocols of the laboratory animal care. These principles were approved by Animal Ethics Committee of Lorestan University of Medical Sciences.

\section{Consent for publication}

Not applicable.

\section{Competing interests}

The authors declare that they have no competing interests.

\section{Publisher's Note}

Springer Nature remains neutral with regard to jurisdictional claims in published maps and institutional affiliations.

\section{Author details}

${ }^{1}$ Razi Herbal Medicine Research Center, Lorestan University of Medical Sciences, Khorramabad, Iran. ${ }^{2}$ Department of Biochemistry, Lorestan University of Medical Science, Khorramabad, Iran. ${ }^{3}$ Department of Anatomical Sciences, Kermanshah University of Medical Sciences, Kermanshah, Iran. ${ }^{4}$ Student Research Committee, Lorestan University of Medical Sciences, Khorramabad, Iran. ${ }^{5}$ Tissue Engineering and Stem Cells Research Center, Shahroud University of Medical Sciences, Shahroud, Iran.

Received: 12 February 2019 Accepted: 8 April 2019

Published online: 20 April 2019

\section{References}

1. Guo S, DiPietro LA. Factors affecting wound healing. J Dent Res. 2010;89(3):219-29.

2. Sadava EE, Krpata DM, Gao Y, Rosen MJ, Novitsky YW. Wound healing process and mediators: implications for modulations for hernia repair and mesh integration. J Biomed Mater Res A. 2014;102(1):295-302.

3. Atiba A, Nishimura M, Kakinuma S, Hiraoka T, Goryo M, Shimada Y, et al. Aloe vera oral administration accelerates acute radiation-delayed wound healing by stimulating transforming growth factor- $\beta$ and fibroblast growth factor production. Am J Surg. 2011:201(6):809-18.

4. Ferrari G, Cook BD, Terushkin V, Pintucci G, Mignatti P. Transforming growth factor-beta 1 (TGF- $\beta 1$ ) induces angiogenesis through vascular endothelial growth factor (VEGF)-mediated apoptosis. J Cell Physiol. 2009;219(2):449-58.

5. Ma J, Wang Q, Fei T, Han J-DJ, Chen Y-G. MCP-1 mediates TGF- $\beta$-induced angiogenesis by stimulating vascular smooth muscle cell migration. Blood. 2007;109(3):987-94.

6. Larsson J, Goumans MJ, Sjöstrand LJ, van Rooijen MA, Ward D, Levéen P, et al. Abnormal angiogenesis but intact hematopoietic potential in TGF- $\beta$ type I receptor-deficient mice. EMBO J. 2001;20(7):1663-73.

7. Kim SI, Kwak JH, Na H-J, Kim JK, Ding Y, Choi ME. TGF- $\beta 1$ activates TAK1 via TAB1-mediated autophosphorylation, independent of TGF- $\beta$ receptor kinase activity in mesangial cells. J Biol Chem. 2009;284(33):22285-96.
8. Sánchez-Elsner T, Botella LM, Velasco B, Corbí A, Attisano L, Bernabéu C. Synergistic cooperation between hypoxia and transforming growth factor- $\beta$ pathways on human vascular endothelial growth factor gene expression. J Biol Chem. 2001;276(42):38527-35.

9. Mason JC, Lidington EA, Ahmad SR, Haskard DO. bFGF and VEGF synergistically enhance endothelial cytoprotection via decay-accelerating factor induction. Am J Phys Cell Phys. 2002;282(3):C578-C87.

10. Ponce CC, Chauffaille MLLF, Ihara SSM, Silva MRR. Increased angiogenesis in primary myelofibrosis: latent transforming growth factor- $\beta$ as a possible angiogenic factor. Rev Bras Hematol Hemoter. 2014;36(5):322-8.

11. Hom DB, Unger GM, Pernell KJ, Manivel JC. Improving surgical wound healing with basic fibroblast growth factor after radiation. Laryngoscope. 2005:115(3):412-22.

12. Jozefczuk J, Drews K, Adjaye J. Preparation of mouse embryonic fibroblast cells suitable for culturing human embryonic and induced pluripotent stem cells. J Vis Exp. 2012;(64). https://doi.org/10.3791/3854.

13. Fronza M, Heinzmann B, Hamburger M, Laufer S, Merfort I. Determination of the wound healing effect of Calendula extracts using the scratch assay with 3T3 fibroblasts. J Ethnopharmacol. 2009;126(3):463-7.

14. Saini P, Al-Shibani N, Sun J, Zhang W, Song F, Gregson KS, et al. Effects of Calendula officinalis on human gingival fibroblasts. Homeopathy. 2012;101(2):92-8.

15. Min YD, Choi CH, Bark H, Son HY, Park HH, Lee S, et al. Quercetin inhibits expression of inflammatory cytokines through attenuation of NF-kappaB and p38 MAPK in HMC-1 human mast cell line. Inflamm Res. 2007;56(5):210-5.

16. Parente LM, Andrade MA, Brito LA, Moura VM, Miguel MP, Lino-Junior Rde $S$, et al. Angiogenic activity of Calendula officinalis flowers $L$. in rats. Acta Cir Bras. 2011;26(1):19-24

17. Patrick K, Kumar S, Edwardson P, Hutchinson J. Induction of vascularisation by an aqueous extract of the flowers of Calendula officinalis $L$. the European marigold. Phytomedicine. 1996;3(1):11-8.

18. Gurtner GC, Werner S, Barrandon Y, Longaker MT. Wound repair and regeneration. Nature. 2008;453(7193):314-21.

19. Schafer M, Werner S. Transcriptional control of wound repair. Annu Rev Cell Dev Biol. 2007;23:69-92.

20. Ganapathy N, Venkataraman SS, Daniel R, Aravind RJ, Kumarakrishnan VB. Molecular biology of wound healing. J Pharm Bioallied Sci. 2012; 4(Suppl 2):S334-7.

21. Isaka YTM, Ando Y, Nakamura H, Kaneda Y, Imai E, Hori M. Transforming growth factor-beta 1 antisense oligode-oxynucleotides block interstitial fibrosis in unilateral ureteral obstruction. Kidney Int. 2000;58:1885-92.

22. Song L, Tian Y, Xu Z-J, Zhang C-P. Adrenaline inhibited cell proliferation and regulated expression of TGF-beta1 and bFGF in cultured human hypertrophic scar fibroblasts via alpha-receptor. EXCLI J. 2008;7:1-12.
Ready to submit your research? Choose BMC and benefit from:

- fast, convenient online submission

- thorough peer review by experienced researchers in your field

- rapid publication on acceptance

- support for research data, including large and complex data types

- gold Open Access which fosters wider collaboration and increased citations

- maximum visibility for your research: over $100 \mathrm{M}$ website views per year

At BMC, research is always in progress.

Learn more biomedcentral.com/submissions 